\title{
CRITICAL MASS IN THE BOARDROOM OF CROATIAN BANKS
}

Tomislava Pavic Kramaric, Marko Miletic

\section{Abstract}

This paper investigates the influence of gender diversity in the boardroom of Croatian banks on their performance. Specifically, we deal with both management and supervisory boards. Moreover, based on critical mass theory, the authors try to find out what constitutes critical mass. Using a static panel analysis on a sample of all commercial banks that operated in the period 2002-2014, three models were estimated with return on assets (ROA), return on equity (ROE) and net interest margin (NIM) as dependent variables. Board structure variables include gender of the chairperson, size of the board, share of women on the board and four dummy variables constructed on critical mass theory, specifically uniform group, skewed group, tilted group and balanced group. Other controls employed in the model include capital adequacy, the growth rate of assets at the bank level, ownership, age and a crisis dummy. The main finding is that when a critical mass of 20\%-40\% of women on the management board has been reached, bank performance improves.

Key words: banks, corporate governance, firm performance, gender equality

JEL classification: $G 21, G 34, J 16, L 25$

\section{INTRODUCTION}

Financial scandals have led to an increasing interest in the relationship between corporate governance and firm performance when control mechanisms are challenged. In this context, the board is considered to be a mechanism for corporate governance, assigned the task of protecting and increasing assets and maximizing the return on corporate investments (VillanuevaVillar, Rivo-López and Lago-Peñas 2016, p. 1).

One of the important elements of board effectiveness is board diversity. According to Tipuric et al. $(2015$, p. 39$)$ the board, as a place of confrontation and harmonization of different views and the various requests of the stakeholders, should be composed of people who have different characteristics, interests and views. Such heterogeneity may have synergistic effects in its work and result in greater efficiency and better decision-making.
This variety of the board can be measured by a number of characteristics, with gender being one of the most important. Requirements for a higher share of female board members are, on the one hand,

Tomislava Pavic Kramaric, PhD

Senior Lecturer

University of Split, University Department of

Professional Studies

E-mail: tpavic@oss.unist.hr

Marko Miletic, PhD

Senior Lecturer

University of Split, University Department of

Professional Studies

E-mail: mamiletic@oss.unist.hr 
motivated by activism to create equal opportunities in the business community, but also with arguments that emphasize the selection and inclusion of individuals with different experiences, knowledge, skills and perspectives as a prerequisite for the effective and efficient operation of the board (Tipuric et al. 2015, p. 40).

This particularly refers to banks. According to de Cabo, Nogués and Nieto (2009, p. 5) gender diversity can be considered an important dimension in gaining better corporate governance of banks. In fact, a higher diversity of perspectives and points of view when perceiving environmental threats and opportunities can be especially important in a sector highly exposed to the risk of contagion and where crises can have disastrous consequences in terms of crippled economies, destabilized governments, and intensified poverty.

Despite seismic movements that have been made in last decades regarding gender diversity in different spheres of human life, there is no doubt that gender diversity is one of the most important issues of the modern age. This is especially the case with gender diversity in the workplace, particularly in leading positions within institutions such as banks. Therefore, the focus of our research is gender diversity in the boardroom of Croatian banks where top positions were traditionally held by men. Specifically, we will try to find out how both management and supervisory board characteristics affect bank performance.

Although there have been numerous works of research that have tried to find a direction in how gender diversity affects corporate performance, only a few have determined a positive effect from gender diversity on firm performance (e.g. Carter, Simkins and Simpson 2003; Campbell and Minguez-Vera 2007; Francoeur, Labelle and Sinclair-Desgagné 2007; Lückerath-Rovers 2011; Barta, Kleiner, \& Neumann 2012). We are not trying here to address this issue from a social and ethical, or even psychological perspective, but merely find if there are financial benefits of gender diversity in the boardroom.

Specifically, we will try to test critical mass theory on the sample of all Croatian commercial banks that operated in the 2002-2014 period. This is particularly significant in light of imposing women quotas on European boards.

Although an EU proposal for a directive to improve female diversity on company boards that would set a mandatory 'procedural quota' of $40 \%$ has not been adopted yet, some countries have already set a minimum compulsory quota of $40 \%$ representation for each gender in the boardroom. The Norwegian quota law was one of the first of its kind in Europe (Crutchley Lending and Vähämaa 2016). In 2005, the Norwegian government passed a quota law requiring Norwegian public limited-liability companies to have at least $40 \%$ of each gender represented on their board of directors. Law enforcement began at the beginning of 2008 and by then all public limited liability companies (with very few exceptions) had already met the requirement of at least 40\% (Torchia, Calabrò and Huse 2011, p. 300 citing Rasmussen and Huse 2011). France, Italy and Belgium have done so for company boards, while Denmark, Greece, Austria, Slovenia and Finland have introduced gender requirements in legislation for the composition of the boards of state-owned companies (CIPD 2015). Germany, however, has recently agreed a new law providing for a 30\% quota for the supervisory boards of the country's largest listed companies from 2016 (European Parliament, The Policy on Gender Equality in Germany 2015). The law on effective gender equality adoption by the Spanish government in 2007 recommends specifically that large companies with more than 250 employees and IBEX 35 gradually appoint women to their boards in order to achieve $40 \%-60 \%$ of each gender (European Commission, The current situation of gender equality in Spain - Country Profile 2012, p. 10).

The European Commission database on women and men in decision-making bodies, (which are usually supervisory boards) which covers gender balance in key positions in the largest publicly listed companies at the European and national levels, shows that women are underrepresented in economic decisionmaking positions in the EU-28. Croatia is no exception. According to data from April 2016, women account for $23 \%$ in the highest decision-making body at the EU level, while in Croatia they make up 22\% (European Commission, Gender Equality 2016).

Our empirical investigation builds explicitly upon critical mass theory, which has been tested by Joecks, Pull and Vetter (2013). Joecks, Pull and Vetter (2013, p. 5-6), citing Kanter (1997) note that, in her analysis of group interaction processes, Kanter constructs four different categories of groups according to their composition: uniform groups, skewed groups, tilted groups and balanced groups. Uniform groups are groups in which all members share the same (visible) characteristic. l.e., with respect to gender, all members of the group are either male or female. Skewed groups are groups in which one dominant type (e.g. the males) controls the few (e.g. the females) and therefore also controls the group and its culture. The few are called "tokens" and are not treated as individuals but as representatives for their category. Kanter suggests that a male dominated skewed group consists of up to $20 \%$ women. Tilted groups are groups with a less extreme distribution. Unlike in skewed groups, 
minority members can ally and influence the culture of the group. They do not stand for all of their kind, instead they represent a subgroup whose members are to be differentiated from each other in their skills and abilities. A male dominated tilted group consists of 20 to $40 \%$ women. In a so-called balanced group, the majority and minority turn into potential subgroups where gender-based differences become less and less important. The focus turns to the different abilities and skills of the men and women. A balanced group with respect to gender representation has 40 to $60 \%$ women.

Compared to their study, our contribution is multi-fold. First, we employ two corporate governance mechanisms, i.e. management and supervisory boards. Second, we measure corporate performance by introducing three dependent variables: ROA, ROE and NIM. Third, our analysis is conducted using a static panel model in comparison to ordinary least squares (OLS) and random effects (RE) regressions used by the aforementioned authors. Finally, new variables are added in the model that try to explain what determines bank profitability, as well as to find what forms the critical mass of women for a bank to perform better.

The paper is structured as follows. After the introduction given in Section 1, Section 2 outlines aspects of corporate governance in the banking sector in Croatia. Section 3 provides insight into previous research on the issue analyzed, while Section 4 describes the model's variables and provides a rationale for the potential effects of each variable on bank performance. Sample construction and econometric specification are given in Section 5, while Section 6 presents main the study's empirical results. Section 7 concludes.

\section{SOME ASPECTS OF CORPORATE GOVERNANCE IN THE CROATIAN BANKING SECTOR}

According to the Credit Institutions Act (Official Gazette No. 59/2013, 19/2015 and 102/2015) banks in Croatia must apply the dual board system, i.e. they should have a management board and a supervisory board. The management board of a bank in Croatia must have at least two members; moreover, the members of the management board must possess adequate collective knowledge, skills and experience required to direct the business of the bank independently without undue influence from other persons, and in particular to understand the bank's activities and its main risks. Furthermore, the members of the supervisory board must possess adequate collective knowledge, skills and the experience required to supervise the business of the bank independently without undue influence from other persons, and in particular to understand the bank's activities and its main risks.

In terms of implementing a quota of at least $40 \%$ of each gender, Croatia encourages a voluntary approach to improving gender balance in company boardrooms.

Figure 1: Women on the Management Boards of Croatian Banks

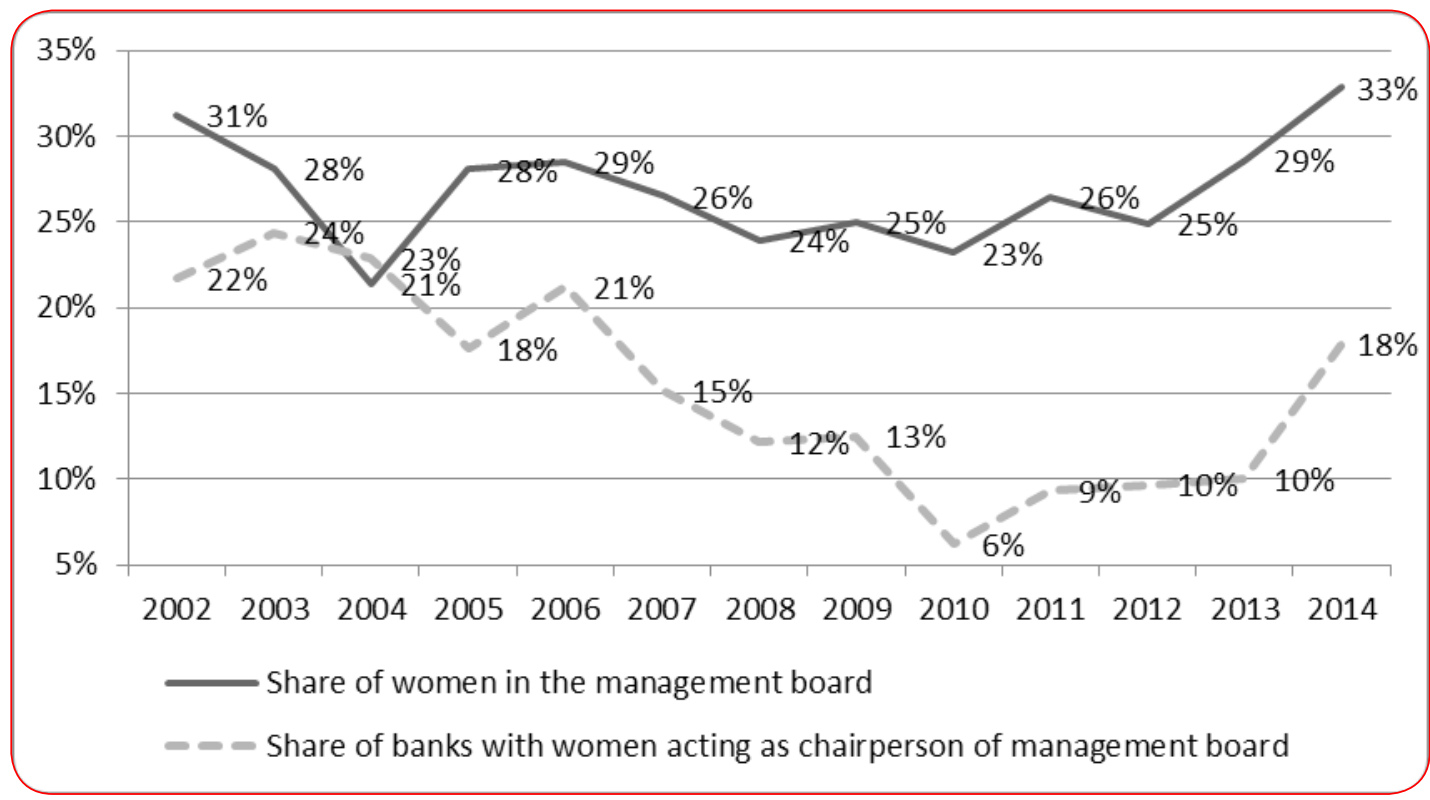

Source: authors' calculation 
On average, the share of women on management boards in the period of 2002-2014 amounted to $27 \%$. As shown in Figure 1, in the total period covered by the analysis the share of women on the management boards of Croatian banks ranged between $21 \%$ and $33 \%$, which peaked in 2014. This increasing trend observed in recent years is particularly welcome, since the share of women on the management boards of Croatian banks is higher than the mandatory quota imposed in some European countries. However, the situation is worrisome when observing data on women acting as chairpersons of management boards. Specifically, in 2010, only 6\% of Croatian banks had a female chairperson.

Another important aspect of the management board is its size. According to the Credit Institutions Act (Official Gazette No. 59/2013, 19/2015 and 102/2015) the management board of a bank must have at least two members who direct the business of the bank and represent it. One of the members of the management board must be appointed chairperson of the management board. In the 2002-2014 period the management board in the Croatian banking sector was on average made up of three members.

As shown in Figure 2, the situation regarding gender diversity in the boardroom of the Croatian banking sector deteriorates when observed in terms of supervisory boards. On average, the share of women on supervisory boards in the period of 2002-2014 amounted to only $17 \%$. In the total period covered by the analysis this share ranged between $13 \%$ and $20 \%$. This is particularly low given the proposed EU
Directive of a $40 \%$ quota for women non-executives. However, the situation is even worse when observing data on women acting as chairpersons of the supervisory board. Specifically, the share of banks with women acting as chairperson of the supervisory board ranged between $3 \%$ and $19 \%$, with a decreasing trend in recent years.

This paper deals with the size of the supervisory board as a feature that might influence performance. It should be noted that the Credit Institutions Act (Official Gazette No. 59/2013, 19/2015) does not stipulate a minimum requirement regarding the overall number of supervisory board members. In the 20022014 period supervisory boards in the Croatian banking sector were on average made up of five members.

\section{REVIEW OF PREVIOUS RESEARCH}

The influence of board composition in terms of gender diversity has been widely explored. Therefore, here we will focus on papers dealing, at least to a certain extent, with critical mass theory. This theory regarding gender diversity on boards has been largely analyzed in the context of women's political representation. However, this is not the case in the field of corporate governance.

Joecks, Pull \& Vetter (2013) examined gender diversity in the boardroom and firm performance using a data set of 151 listed German firms for the years 20002005. The authors compared firm performance for different board types according to the classification

Figure 2: Share of Women in the Supervisory Boards of Croatian Banks

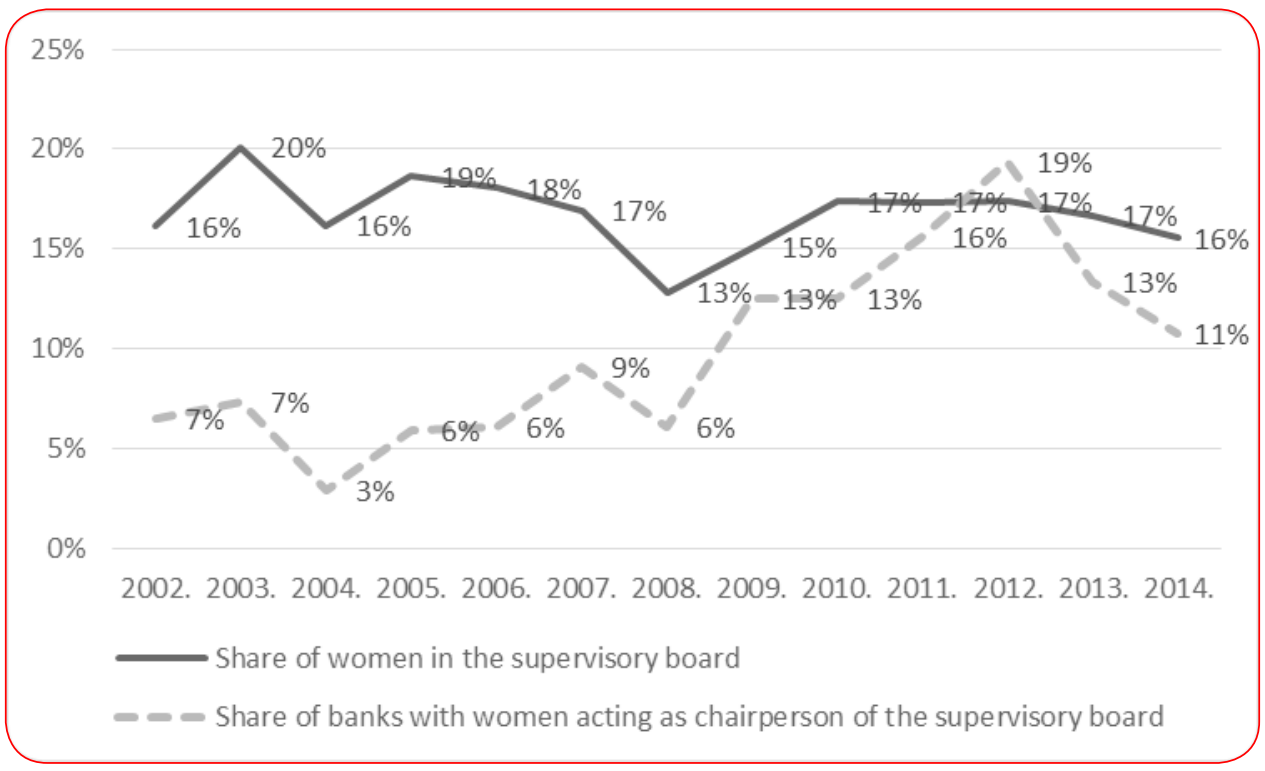

Source: authors' calculation 
by Kanter (1977), and then analyzed the link between board type and firm performance in a multivariate regression analysis. They then regressed firm performance on their measure of gender diversity in both its linear and quadratic terms to account for potential nonlinearities and to endogenously determine the "critical mass" of women on the supervisory board. Since an aim of their research was to further substantiate results on the critical mass of women in the boardroom, the authors conducted a regression on the apparent "magic number" of women in the boardroom. In all models, Ordinary Least Squares estimators (OLS) with robust standard errors and firm clusters were used. They found evidence of the critical mass of female representatives on the board to be reached at a share of about 30\%. Over and above that threshold, the performance of a more diverse board exceeded that of a completely male board. Joecks, Pull and Vetter (2013) further substantiated their results, distinguishing firms with (a) no woman on their supervisory board from firms with (b) one woman on the board, (c) two women on the board and (d) three or more women on the board. Running OLS and RE-regressions the authors found that having three or more women on the board significantly increases ROE as compared to having only one woman on the board.

In order to study the effect on boardroom dynamics of increasing female presence Konrad and Kramer (2006) interviewed 50 women directors, 12 CEOs (nine of them male), and seven corporate secretaries (one of them male) at Fortune 1000 companies. Their findings exposed dramatic differences among boards with one, two, or at least three women directors. They point out that solo women on boards often feel isolated and marginalized. When they are effective, it is not because of but in spite of being the only woman. Adding a second woman to a board helps reduce the sense of isolation, but it does not always cause change and may create its own difficulties. Two women may be perceived as a separate group and may find they have to be careful not to appear to be conspiring. What's more, they may not be distinguished from each other. Their research shows that a clear shift occurs when boards have three or more women: women tend to be regarded by other board members not as "female directors" but simply as directors, and they do not report being isolated or ignored. Three women or more can also change the dynamic on an average-size board.

De Cabo, Nogués and Nieto (2009) analyzed 612 EU-25 banks using the BankScope database. They included variables such as bank size, ROA, cost to income ratio and leverage. To consider the risk that each bank assumes as well as its dynamism, the authors have included the log of the standard deviation of ROA over the study period in order to control for bank risk, and the mean of the growth rate of total assets over the same period as a proxy for bank growth. Moreover, they have also considered dummy explanatory variables that control for the country of origin of the bank, with Germany as the reference country, the type of bank activity, with commercial bank the reference category, and whether banks are listed in the stock market. The banks' board size was considered as a proxy for the preference for homogeneity. They have found that women are less likely to appear on those boards of directors where there is some evidence that monitoring plays a minor role, that is, those with a small board, where preference for homogeneity is stronger. Additionally, banks with lower risk have a higher proportion of women. There is also some evidence of Becker's discrimination, given that those banks that have more women, and therefore are less likely to present discrimination bias, are precisely those that have greater growth rates in their total assets. Finally, the authors have also found that there are cultural differences that explain part of the heterogeneity in the presence of women on the boards, since they have found significant differences among European countries.

Drawing on critical mass theory, Torchia, Calabrò and Huse (2011) address the question of whether an increased number of women directors results in the build-up of critical mass that substantially contributes to firm innovation. Tests are conducted on a sample of 317 Norwegian firms during 2005/2006 and the first half of 2006 using a questionnaire of 256 questions. The dependent variable (organizational innovation) was measured with several items on a seven-point Likert-type scale addressing the board members' perceptions on firm innovation, highlighting the different perspectives of individuals involved in the innovation process. The number of women directors served as the independent variable. Specifically, the sample was divided into four groups based on their number of women. In particular, the first group included firms with boards with no women; the second had only one woman, the third had two women directors and the last had at least three women directors. To control for different variables influencing the level of firm organizational innovation, authors included variables such as firm size, the number of employees provided by the CEOs, dummy variable for industrial sector, board demographic characteristics (board size, CEO and chairperson tenure, CEO and chairperson gender), the length of board meetings and the directors' knowledge and competence. Their findings suggest that boards with one or two women directors are unable 
to contribute to firm organizational innovation. By validating at least three women directors as the size that the minority group has to reach to make a significant contribution to firm organizational innovation, their findings show that it is possible to operationalize the critical mass construct.

\section{DESCRIPTION OF VARIABLES}

The dependent variables employed in the model measuring performance are accounting measures such as ROA and ROE, as well as NIM. Since only a small fraction of Croatian banks are listed on the stockexchange, a stock-performance measure could not be used. ROA is calculated by dividing a company's after tax annual profits by its total assets. In order to make the results more robust and less sensitive to how profitability is measured, the authors wanted to test for the effect of board composition on other measures of profitability apart from ROA. Therefore, the ROE variable was introduced in the model, which is calculated by dividing a company's after tax annual profits by its total equity. These variables are often employed as measures of bank performance (e.g. Athanasoglou, Brissimis and Delis 2005; Dietrich and Wanzenried 2011). Moreover, the dependent variable NIM also often serves as a performance measure because it focuses on profit earned on interest activities (e.g. Ben Naceur 2003; Bonin, Hasan and Wachtel 2004; Sameh, Bouzgarrou and Louhichi 2016).

The explanatory variables, which refer to board composition, are described below.

The gender of the chairperson of the management board (CHAIR_MB_dummy) and supervisory board (CHAIR_SB_dummy) are included in the model as dummy variables with 0 representing male presidents and 1 female.

The share of women in the management board (SHARE_W_MB) and supervisory board (SHARE_W_ $\mathrm{SB}$ ) is calculated as the number of board female members divided by the total number of board members.

Studies show mixed effects from gender diversity on performance. Some find that gender diversity on boards is associated with greater profitability (Herring 2009), other studies find women have neutral effects on performance (Farrell and Hersch 2005; Carter et al. 2010; Dobbin and Jung 2011), while Shrader, Blackburn and Illes (1997) find in some tests that companies with greater gender diversity underperform in terms of profitability. Although the findings on the board gender diversity - bank corporate performance relation suggest that banks usually do not benefit from higher participation from women on boards, greater representation of women on boards is often observed from positive perspective. According to the resource based theory of competitive advantage, we assume that banks utilizing a high fraction of women on their boards would perform better. As stated by Pathan and Faff (2013), women spend more effort on their tasks and, accordingly, could improve board effectiveness in terms of decision making and information flow. A key factor, as documented by Fields and Keys (2003, p. 13), in diversity's successful impact on firm performance is the value found in the heterogeneity of ideas, experiences, and innovations that diverse individuals bring to the firm. Therefore, we expect a positive sign for the variables gender of the chairperson of the management board and supervisory board, as well as share of women in both management and supervisory boards.

Diversity as variety conceptualizes categorical differences across the relevant characteristics between group members, with variety being commonly measured by both Blau's index and Shannon-Wiener entropy (Solanas, Selvan, Navarro and Leiva 2012). Therefore, the authors applied this concept in order to measure the diversity of the management and supervisory board.

The Blau index, also known as the Simpson index, measures gender diversity on the management board (BLAU_MB) and supervisory board (BLAU_SB), taking into account the number of gender categories (two) as well as the evenness of the distribution of board members among them. It is measured as:

$$
1-\sum_{i=1}^{n} p_{i}^{2}
$$

where $p_{i}$ is the percentage of board members in each category (men and women) and $n$ is the total number of board members. The values of the Blau index for gender diversity range from 0 to a maximum of 0.5 , which occurs when the board comprises an equal number of men and women (Campbell and MínguezVera 2008, p. 442).

The Shannon index, or Shannon-Wiener entropy, measures gender diversity on the management board (SHANNON_MB) and supervisory board (SHANNON_ $\mathrm{SB})$ as well. It is calculated as:

$$
-\sum_{i=1}^{n} p_{i} \ln p_{i}
$$

where $p_{i}$ is the percentage of board members in each category (men and women) and $n$ is the total number of board members. The minimum value of Shannon index is zero and diversity is maximized when both genders are represented in equal proportions, at which point the Shannon index amounts to 0.69. Being a logarithmic measure of diversity it is 
more sensitive to differences in small relative abundances (Baumgartner 2006). The authors also expect these diversity measures to positively influence performance. This assumption is built upon lles and Auluck (1993), cited by Shrader, Blackburn and Illes (1997, p. 356), who found that diverse work forces were beneficial to firms because they facilitated team problem solving and synergy. Furthermore, the ability to manage diversity fostered the incorporation of various perspectives into organizational decision-making, and firms that united a wider range of participants performed well.

The size of the management board (LN_SIZE_MB) and supervisory board (LN_SIZE_SB) variables are calculated as natural logarithms of the total number of board members and are an important feature of the board. As reported by Lipton and Lorsch (1992, p. 65), in large boards it becomes more difficult for all of the members to express their ideas and opinions in the limited time available during board meetings. Moreover, Jensen (1993, p. 865) emphasizes that keeping boards small can help improve their performance, stating that when a board gets beyond an optimal number of people (seven or eight) they are less likely to function effectively. Furthermore, some literature finds evidence that supports the view that a smaller board is related to better firm performance (Yermack 1996; Huang et al. 2011). However, some researchers find a positive relation between board size and corporate performance (Dalton 1999) whereas Hardwick, Adams and Zou (2011) find no evidence of board size on profit efficiency. Based on previous studies, there is unclear empirical evidence on the relation between firm performance and board size. Therefore, the expected influence of this variable on performance in ambiguous.

Due to the specific characteristics of different industries that affect their corporate performance, we have identified control variables frequently employed in empirical studies in the banking field. These are explained below.

According to Ongore and Kusa (2013, p. 240) capital adequacy shows the internal strength of the bank to withstand losses during crisis. It is directly proportional to the resilience of the bank to crises. Since it should capture the general average safety and soundness of the financial institutions (Staikouras and Wood, 2004), capital adequacy (CAP) was introduced to the model while it was obtained directly from various issues of Banks Bulletin of Croatian National Bank (CNB). With the aim of preventing failures and protecting the interests of depositors, it is necessary to require banks to maintain a high level of capital adequacy. According to the Credit Institutions Act (Official
Gazette No. 59/2013, 19/2015 and 102/2015) a bank must at all times ensure an amount of capital that is proportionate to the nature, scale and complexity of its activities as well as the risks to which it is or might be exposed to while providing services.

Since 1 January 2014, the framework for determining the capital and capital ratios of credit institutions has been governed by the Regulation (EU) No 575/2013 and Directive 2013/36/EU, which was transposed into Croatian legislation via the Credit Institutions Act. The new rules brought new, stricter definitions of capital and a broader scope of risk coverage, as well as different regulation of capital ratios. The minimum total capital ratio amounted to $8 \%$, while common equity tier 1 capital ratio was $4.5 \%$ and tier 1 capital ratio 6\%. In addition, also since 1 January 2014, credit institutions have been obligated to maintain a capital conservation buffer of $2.5 \%$ of total exposure, while in 19 May 2014 the requirement for systemic risk was set at $1.5 \%$ of the total risk exposure for all credit institutions and an additional $1.5 \%$ for institutions of relatively larger scope and complexity of operations (CNB, Banks Bulletin No. 29, 2016). Given the abovementioned, we expect capital adequacy to positively affect performance. A similar finding was obtained by Demirgüç-Kunt and Huizinga (1999).

The growth rate of assets (GROWTH_ASSETS) variable is calculated as follows: (Assets A $_{t}-$ Assets $_{t-1}$ ) / Assets $_{t-1}$. The authors expect that banks with increasing growth rates should experience improved performance. Demirgüç-Kunt and Huizinga $(2011$, p. 3) show that asset growth increases profitability indicators for most banks, worldwide. The authors note, however, that for the vast majority of banks, growth appears to offer a trade-off between risk and return.

The size variable is introduced to account for the existence of economies or diseconomies of scale in the banking market. It is calculated as the natural logarithm of total assets (LN_ASSETS). The size variable is expected to positively influence performance since the conventional wisdom is that, as stated by Lee $(2009$, p. 200), larger firms tend to be more profitable than their smaller counterparts, either due to efficiency gains or higher market power. The view suggesting that large companies generally outperform smaller ones because they realize economies of scale is supported by the work by Demirgüç-Kunt and Huizinga (2011). As stated by Athanasoglou, Brissimis and Delis (2005), the effect of a growing size on profitability has been proved to be positive to a certain extent, although in research by Demirgüç-Kunt and Huizinga (2011) size proved to be insignificant in all of the relevant regressions. Moreover, for banks that become extremely large, the effect of size could 
be negative due to bureaucratic factors and other reasons (Athanasoglou, Brissimis and Delis 2005). Therefore, the influence of the size variable on profitability is ambiguous.

The market share variable (MS) is calculated as assets of an individual bank divided by the total assets of the banking industry in a particular year. It is employed in the model to test the relative-market power hypothesis that argues that only large banks with some "brand identification" can influence pricing and raise profits (Jeon and Miller 2005, p. 11). Therefore, a positive relationship of this variable on bank performance is expected.

The majority of Croatian banks are foreign owned: specifically, 17 out of 27 banks were foreign owned in 2014. This is $90.09 \%$ of total assets. To control for this, an ownership dummy (OWN) variable was introduced in the model with 0 referring to foreign owned banks and 1 for domestic ones. As it the case with most posttransition countries, the variety and quality of banking products offered increased with the entrance of foreign capital. Therefore, foreign owned banks are expected to perform better, which is consistent with the notion that international investors facilitate the transfer of technology and know-how to newly privatized banks (Bonin, Hasan and Wachtel 2004, p. 23). On the contrary, the hypothesis that domestic ownership leads to more profitable banks can be explained by Fok, Chang and Lee $(2004$, p. 91) stating that foreign banks do not rely on local deposits and can raise equity capital internationally.

The age of a bank (AGE) as a control variable was calculated as the natural logarithm of the number of years the bank operated in the market, i.e. as the current year of the analysis reduced by the foundation year of the bank. The expected effect of a bank's age on performance is ambiguous. For example, Coad, Segarra and Teruel $(2013$, p. 26) support evidence that firms improve with age, finding that ageing firms experience rising levels of productivity, profits, larger size, lower debt ratios, and higher equity ratios. But they also find that older firms have lower expected growth rates of sales, profits and productivity, lower profitability levels (when other variables are controlled for), and also that they appear to be less capable of converting employment growth into growth of sales, profits and productivity.

Since the time span of the analysis comprises noncrisis as well as crisis years, a year dummy variable (CRISIS_dummy) was introduced to the analysis. It takes the value 1 if the country is going through crisis and 0 otherwise. The authors distinguish the period prior to the acute crisis starting with the collapse of Lehman Brothers in September 2008 (Schuknecht, von Hagen and Wolswijk 2010) but also take into account data on GDP growth in Croatia. The basis for selection of the year in which the dummy variable takes the value 1 is the negative growth rate of GDP. Specifically, negative GDP growth rates were registered in the 2009-2014 period, whereas during 20022008 this variable takes a value of 0 . It is expected that crisis years negatively affect performance.

A brief description and measurement of variables is provided in Appendix 1.

The data used in this research were drawn from annual reports published by the CNB and, for some banks, the Zagreb Stock Exchange (ZSE). Variables dealing with corporate governance were manually collected and calculated using annual reports and double checked with data from banks' corporate web pages. The age variable was also calculated using manually collected data on establishment data from banks' corporate web pages. The macroeconomic data was taken from CNB web pages relating to Statistics main economic indicators.

\section{SAMPLE CONSTRUCTION AND ECONOMETRIC SPECIFICATION}

Our sample consists of all Croatian commercial banks that operated in the 2002-2014 period. However, as the number of banks in our sample changes over time due to new entrances or exits in the industry, our sample is an unbalanced panel. Moreover, we excluded those banks that were active in only one year of the total observed period (a total of three banks) and banks that have the falsely positive financial indicator ROE (totally two banks). There were, on average, 33.61 banks per year, making for a total of 437 observations.

Descriptive statistics of the variables explained in Section 4 are given in Table 1.

A pairwise correlation matrix is given in Appendix 2. available at the following link http://personal.oss. unist.hr/ mamiletic/table2.pdf. As can be seen from the table, a multicollinearity problem occurs between some variables, with collinearity coefficients above 0.7. Therefore, these were omitted from further analysis and comprise the Blau index (BLAU_MB and BLAU_ $\mathrm{SB}$ ), Shannon index (SHANNON_MB and SHANNON_ SB), as well as size based on assets (LN_ASSETS) and market share (MS) variables. 
Table 1: Descriptive Statistics

\begin{tabular}{|c|c|c|c|c|c|}
\hline Variable & Obs & Mean & Std. Dev. & Min & Max \\
\hline ROA & 437 & -0.0920 & 4.8520 & -74.5946 & 4.9907 \\
\hline ROE & 437 & -0.5088 & 31.3988 & -375.2120 & 27.1487 \\
\hline NIM & 437 & 3.7540 & 8.1989 & -0.6700 & 171.4029 \\
\hline CAP & 437 & 21.5912 & 17.7380 & 6.1300 & 220.6800 \\
\hline GROWTH_ASSETS & 437 & 15.1890 & 35.7050 & -83.7441 & 421.3304 \\
\hline LN_ASSETS & 437 & 14.5194 & 1.7903 & 9.2808 & 18.4873 \\
\hline MS & 437 & 2.9576 & 5.5764 & 0.0000 & 26.8645 \\
\hline OWN & 436 & 0.5665 & 0.4961 & 0 & 1 \\
\hline AGE & 437 & 2.5829 & 0.8168 & 0.0000 & 4.6052 \\
\hline CRISIS_dummy & 437 & 0.3570 & 0.4797 & 0 & 1 \\
\hline CHAIR_MB_dummy & 437 & 0.1602 & 0.3672 & 0 & 1 \\
\hline LN_SIZE_MB & 437 & 1.0025 & 0.3893 & 0.6931 & 2.0794 \\
\hline SHARE_W_MB & 437 & 0.2697 & 0.2689 & 0.0000 & 1.0000 \\
\hline BLAU_MB & 437 & 0.2496 & 0.2255 & 0.0000 & 0.5000 \\
\hline SHANNON_MB & 437 & 0.3569 & 0.3187 & 0.0000 & 0.6931 \\
\hline UNIFORM_MB_dummy & 436 & 0.4358 & 0.4964 & 0 & 1 \\
\hline SKEWWED_MB_dummy & 437 & 0.0366 & 0.1880 & 0 & 1 \\
\hline TILTED_MB_dummy & 435 & 0.2207 & 0.4152 & 0 & 1 \\
\hline BALANCED_MB_dummy & 437 & 0.2975 & 0.4577 & 0 & 1 \\
\hline CHAIR_SB_dummy & 437 & 0.0961 & 0.2951 & 0 & 1 \\
\hline LN_SIZE_SB & 437 & 1.5311 & 0.3359 & 0.6931 & 2.3979 \\
\hline SHARE_W_SB & 437 & 0.1685 & 0.2189 & 0.0000 & 1.0000 \\
\hline BLAU_SB & 437 & 0.1845 & 0.1879 & 0.0000 & 0.5000 \\
\hline SHANNON_SB & 437 & 0.2788 & 0.2771 & 0.0000 & 0.6931 \\
\hline UNIFORM_SB_dummy & 437 & 0.4805 & 0.5002 & 0 & 1 \\
\hline SKEWWED_SB_dummy & 437 & 0.1121 & 0.3159 & 0 & 1 \\
\hline TILTED_SB_dummy & 437 & 0.2723 & 0.4457 & 0 & 1 \\
\hline BALANCED_SB_dummy & 437 & 0.0984 & 0.2982 & 0 & 1 \\
\hline
\end{tabular}

Source: authors' calculation

For the purpose of econometric data analysis, we employed static unbalanced panel data analysis. Model (1) forms the basis of our estimation.

$$
\begin{aligned}
& Y_{i t}=c+\sum_{k=1}^{K} \beta_{k} X_{i t}^{k}+\varepsilon_{i t} \\
& \varepsilon_{i t=Z_{i}}+u_{i t},
\end{aligned}
$$

where:

- $Y_{\text {it }}$ is the profitability of bank $i$ at time $t$, with $i=$ $1, \ldots, \mathrm{N} ; \mathrm{t}=1, \ldots, \mathrm{T}$ presented with three different measures of profitability: ROA, ROE and NIM. By iterating these profitability measures, we account for three different models depending on the dependent variable used.
- $\mathrm{X}_{\mathrm{it}}$ are $\mathrm{k}$ independent variables as discussed above.

$\varepsilon_{i t}$ is the disturbance with $z_{i}$ being the unobserved bank-specific effect and $u_{i t}$ being the idiosyncratic error. The presented model is a one-way error component regression model where $z_{i} \sim \operatorname{IIN}\left(0, \sigma_{z}^{2}\right)$ and independent of $u_{i t} \sim \operatorname{IIN}\left(0, \sigma_{u}^{2}\right)$

Three models were employed in the research; depending on the dependant variable used (ROA, ROE and NIM).

Before the panel analysis was conducted, the stationarity in a panel dataset was tested. Because the sample is unbalanced, a Fisher-type unit-root test based on an augmented Dickey-Fuller test was implemented. The presence of unit roots was tested in all 
variables except dichotomous. The results are shown in Table 2.

The results for the variables CAP, LN_SIZE_MB and SHARE_W_SB showed that these variables are not stationary. After finding the first difference for these variables, the same unit-root test was conducted and the result showed that the first differences of these variables were stationary. After that, differenced variables were used in research. Instead of the variables CAP, LN_SIZE_MB and SHARE_W_SB, the variables D_CAP, D_LN_SIZE_MB and D_SHARE_W_SB were included in model.

Various tests were used in order to determine which static panel (pooled panel, static panel with fixed effects or static panel with random effects) would be the most appropriate for this research. An $\mathrm{F}$ test was applied to analyze the applicability of the panel with fixed effects compared to a pooled panel, whereas a Lagrange Multiplier test was used to analyze the applicability of panel with random effects

Table 2: Fisher-type unit-root test

\begin{tabular}{|l|c|c|}
\hline Variables & $\begin{array}{c}\text { Inverse chi- } \\
\text { squared p-value }\end{array}$ & $\begin{array}{c}\text { Inverse normal } \\
\text { p-value }\end{array}$ \\
\hline ROA & 0.0325 & 0.0663 \\
\hline ROE & 0.0639 & 0.0789 \\
\hline NIM & 0.0000 & 0.0004 \\
\hline CAP & 0.0005 & 0.1049 \\
\hline GROWTH_ASSETS & 0.0000 & 0.0000 \\
\hline AGE & 0.0000 & 0.0000 \\
\hline LN_SIZE_MB & 0.4514 & 0.0136 \\
\hline SHARE_W_MB & 0.0000 & 0.0000 \\
\hline LN_SIZE_SB & 0.0000 & 0.0000 \\
\hline LN_SIZE_SB & 0.0000 & 0.0000 \\
\hline SHARE_W_SB & 0.6780 & 0.1618 \\
\hline
\end{tabular}

Source: authors' calculation

Table 3: Tests for determination of which static panel would be the most appropriate

\begin{tabular}{|l|c|c|l|}
\hline Tests & \multicolumn{1}{|c|}{ ROA } & ROE & NIM \\
\hline F test & $8.1600^{* * *}$ & $4.0700^{* * *}$ & 1.1400 \\
\hline $\begin{array}{l}\text { Breusch and Pagan } \\
\text { Lagrangian multiplier }\end{array}$ & $44.4100^{* * *}$ & $30.2500^{* * *}$ & 0 \\
\hline Hausman test & $169.1400^{* * *}$ & $96.7500^{* * *}$ & \\
\hline
\end{tabular}

*** Statistically significant at the $1 \%$ level,

Source: authors' calculation compared to a static pool panel. Finally, the applicability between models with fixed and random effects was determined using a Hausman test. The results of this test are shown in Table 3.

A static model with fixed effects proved to be the most appropriate when analyzing the effect on profitability measured with ROA and ROE. On the other hand, when analyzing the effect on profitability via the NIM variable, the static pooled model proved to be the most appropriate. In this case, the Hausman test was not conducted, since the $\mathrm{F}$ test and Lagrange Multiplier test showed that the pooled model is appropriate in comparison to models with fixed and random effects.

The Breusch-Pagan test for heteroscedasticity also fit into the research. The P-value was 0,0000 , which showed that heteroscedasticity was present. Heteroscedasticity causes standard errors to be biased so robust standard errors were used in the research.

\section{EMPIRICAL FINDINGS}

The empirical results for all three models, i.e. the models with ROA, ROE and NIM used as dependent variables, are presented in Table 4, while their interpretation follows.

As expected, capital adequacy (CAP) has a positive impact on performance. It is significant in models where performance is measured with ROA. It stands for the internal strength of the bank, i.e. for its safety and soundness. As already stated, a similar finding was obtained by Demirgüç-Kunt and Huizinga (1999). Moreover, Pessarosi and Weill (2013) find an increase in capital requirements has a positive effect on cost efficiency. According to Holmstrom and Tirole (1997), Allen, Carletti and Marquez (2011) and Mehran and Thakor (2011), cited in Pessarossi and Weill (2013, p. 5), by increasing the surplus generated in the bank-borrower relationship and by improving monitoring incentives, capital ratios have a positive effect on bank's profitability.

When ROA is used as a dependent variable, the ownership variable (OWN) positively affects performance, suggesting that domestic ownership leads to banks that are more profitable. Fok, Chang and Lee $(2004$, p. 91) note that due to diversification and the resulting lower cost of capital, foreign banks might provide a price advantage to borrowers in host countries by charging lower interest rates than domestic banks, which can lead to lower profitability levels.

In all models, whether ROA, ROE or NIM are used as dependent variables, AGE significantly and negatively affects performance. Loderer and Waelchli (2010, p. 
Table 4: Parameter Estimates of Static Panel Model

\begin{tabular}{|c|c|c|c|}
\hline & ROA & ROE & NIM \\
\hline D_CAP & $\begin{array}{c}0.3418^{* * *} \\
(0.0486)\end{array}$ & $\begin{array}{c}2.0401 \\
(1.4588)\end{array}$ & $\begin{array}{c}0.4346 \\
(0.1934)\end{array}$ \\
\hline GROWTH_ASSETS & $\begin{array}{l}-0.0138 \\
(0.0152)\end{array}$ & $\begin{array}{l}-0.0023 \\
(0.0375)\end{array}$ & $\begin{array}{c}0.0160 \\
(0.2599)\end{array}$ \\
\hline OWN & $\begin{array}{l}1.0379 * * \\
(0.4672)\end{array}$ & $\begin{array}{c}9.4098 \\
(6.6842)\end{array}$ & $\begin{array}{c}0.3355 \\
(0.8053)\end{array}$ \\
\hline AGE & $\begin{array}{c}-0.7722^{* *} \\
(0.3142)\end{array}$ & $\begin{array}{l}-8.0714^{*} \\
(4.7452)\end{array}$ & $\begin{array}{c}-1.2441^{* * *} \\
(0.4031)\end{array}$ \\
\hline CRISIS_dummy & $\begin{array}{c}-0.8517^{* * *} \\
(0.2048)\end{array}$ & $\begin{array}{c}-7.8397^{* * *} \\
(2.8414)\end{array}$ & $\begin{array}{l}-1.4191 \\
(1.7210)\end{array}$ \\
\hline CHAIR_MB_dummy & $\begin{array}{c}0.0212 \\
(0.2753)\end{array}$ & $\begin{array}{c}4.7223 \\
(3.7229)\end{array}$ & $\begin{array}{c}0.5371 \\
(1.1840)\end{array}$ \\
\hline D_LN_SIZE_MB & $\begin{array}{c}0.1276 \\
(0.4525)\end{array}$ & $\begin{array}{c}3.5509 \\
(5.4589)\end{array}$ & $\begin{array}{c}6.6798 \\
(6.4593)\end{array}$ \\
\hline SHARE_W_MB & $\begin{array}{l}-0.1930 \\
(1.0953)\end{array}$ & $\begin{array}{l}-18.4975 \\
(23.1397)\end{array}$ & $\begin{array}{c}0.5023 \\
(1.9883)\end{array}$ \\
\hline $\begin{array}{r}\text { UNIFORM_MB } \\
\text { dummy }\end{array}$ & $\begin{array}{c}0.1212 \\
(0.5128)\end{array}$ & $\begin{array}{c}-7.6925 \\
(10.4754)\end{array}$ & $\begin{array}{c}9.7300 \\
(10.6095)\end{array}$ \\
\hline $\begin{array}{r}\text { SKEWWED_MB } \\
\text { _dummy }\end{array}$ & $\begin{array}{c}0.0544 \\
(0.2283)\end{array}$ & $\begin{array}{l}-0.4997 \\
(4.7622)\end{array}$ & $\begin{array}{c}30.8692^{* * *} \\
(10.2753)\end{array}$ \\
\hline TILTED_MB_dummy & $\begin{array}{l}0.3699 * \\
(0.2098)\end{array}$ & $\begin{array}{c}2.0138 \\
(4.0910)\end{array}$ & $\begin{array}{c}7.0912 \\
(10.6548)\end{array}$ \\
\hline $\begin{array}{r}\text { BALANCED_MB } \\
\text { _dummy }\end{array}$ & $\begin{array}{c}0.3169 \\
(0.26407)\end{array}$ & $\begin{array}{c}4.6626 \\
(4.4406)\end{array}$ & $\begin{array}{c}9.7571 \\
(10.7558)\end{array}$ \\
\hline CHAIR_SB_dummy & $\begin{array}{l}-0.3688 \\
(0.3759)\end{array}$ & $\begin{array}{c}2.8893 \\
(5.6042)\end{array}$ & $\begin{array}{l}-2.5787^{*} \\
(1.3895)\end{array}$ \\
\hline LN_SIZE_SB & $\begin{array}{l}1.4586^{* *} \\
(0.6660)\end{array}$ & $\begin{array}{c}3.2074 \\
(6.5963)\end{array}$ & $\begin{array}{l}-0.2099 \\
(1.3759)\end{array}$ \\
\hline D_SHARE_W_SB & $\begin{array}{l}-0.7074 \\
(0.5717)\end{array}$ & $\begin{array}{l}-29.5898^{*} \\
(16.6433)\end{array}$ & $\begin{array}{l}-9.4080^{*} \\
(5.3179)\end{array}$ \\
\hline UNIFORM_SB_dummy & $\begin{array}{l}-0.8574^{*} \\
(0.4617)\end{array}$ & $\begin{array}{l}-4.9002 \\
(5.9261)\end{array}$ & $\begin{array}{c}1.8571 \\
(3.4827)\end{array}$ \\
\hline $\begin{array}{r}\text { SKEWWED_SB } \\
\text { dummy }\end{array}$ & $\begin{array}{l}-0.6029 \\
(0.3983)\end{array}$ & $\begin{array}{l}-0.5247 \\
(5.8570)\end{array}$ & $\begin{array}{c}0.3324 \\
(3.1961)\end{array}$ \\
\hline TILTED_SB_dummy & $\begin{array}{c}0.2084 \\
(0.3260)\end{array}$ & $\begin{array}{c}4.5012 \\
(7.4471)\end{array}$ & $\begin{array}{l}-0.9304 \\
(3.5784)\end{array}$ \\
\hline $\begin{array}{r}\text { BALANCED_SB } \\
\text { dummy }\end{array}$ & $\begin{array}{l}-0.4046 \\
(0.4178)\end{array}$ & $\begin{array}{c}-9.8574 \\
(10.7318)\end{array}$ & $\begin{array}{c}1.2484 \\
(3.9078)\end{array}$ \\
\hline constan & $\begin{array}{c}0.0668 \\
(1.5187) \\
\end{array}$ & $\begin{array}{c}20.7561 \\
(24.0655) \\
\end{array}$ & $\begin{array}{c}-0.9096 \\
(12.3036)\end{array}$ \\
\hline Model $p$ value & 0.0000 & 0.0000 & 0.0000 \\
\hline R2 within & 0.4118 & 0.2051 & 0.0202 \\
\hline $\mathrm{R} 2$ between & 0.0001 & 0.0932 & 0.7957 \\
\hline $\mathrm{R} 2$ overall & 0.0373 & 0.0720 & 0.0008 \\
\hline
\end{tabular}

$* * * * * *$ Statistically significant at the; $10 \%, 5 \%, 1 \%$ level, respectively. Standard error are between parentheses.

Source: authors' calculation
1) support the negative influence of age on performance, stating that corporate aging could reflect a cementation of organizational rigidities over time. Accordingly, costs rise, growth slows, assets become obsolete, and investment and R\&D activities decline. In addition, older firms are more likely to have a rigid administrative process and more bureaucracy.

Another variable that significantly and negatively affects performance when performance is measured with ROA, but also with ROE, is the crisis variable (CRISIS_dummy) suggesting the procyclical nature of bank profitability. Due to the negative context of crisis, such a finding was expected. This is explained by Athanasoglou, Brissimis and Delis (2005, p. 17) stating that lending could decrease during cyclical downswings, since such periods are normally associated with increased risk. In a similar context, provisions held by banks will be higher due to the deterioration of the quality of loans, and capital could also have procyclical behaviour, as equity tends to follow the phase of the cycle. They explain further that demand for credit and stock market transactions would be strengthened substantially during economic booms and the interest margin may widen. Therefore, revenues could grow faster than costs, leading to increased profits, while the opposite may hold true during economic slowdowns.

Corporate governance variables that significantly influence performance vary depending on the dependent variable being used. When ROA is used as the dependent variable, TILTED_MB_ dummy, size of the supervisory board and UNIFORM_SB_dummy significantly affect performance. Specifically, the positive effect of the tilted groups variable in management board suggests support for a critical mass of women in the boardroom, as proposed by Joecks, Pull and Vetter (2013) citing Kanter (1997). Furthermore, the size of the supervisory board also has a significant and positive effect on performance, suggesting that larger boards 
bring additional value-added expertise. As stated by Dalton (1999, p. 674), resource dependence theory is the primary foundation for the perspective that larger boards will be associated with higher levels of firm performance. The negative effect of uniform group in the supervisory boards also speaks in favour of gender diversity in the boardroom, since completely male supervisory boards inhibit performance measured with ROA.

In models where performance is measured with both ROE and NIM, the variable share of women ( $D_{-}$ SHARE_W_SB) in the supervisory board negatively and significantly affects performance, suggesting that adding more women on boards inhibits performance. As stated by Galinsky et al. (2015, p. 744) diversity can incite detrimental forms of conflict and resentment.

Furthermore, in the model with NIM acting as dependent variable, the gender of the chairperson of the supervisory board (CHAIR_SB_dummy) and SKEWED_ MB_dummy significantly affect performance. The negative sign of the chairperson of the supervisory board (CHAIR_SB_dummy) variable suggests that banks with a male acting as chairperson of the supervisory board would underperform in terms of profitability, which speaks in favour of greater gender diversity in the boardroom as documented by Carter, Simkins and Simpson (2003), Erhardt, Werbel and Shrader (2003), Herring (2009) and Pavic Kramaric, Milun and Pavic (2016), to name a few. Furthermore, as documented by the variable SKEWED_MB_dummy, gender also appears to play a significant role in determining profitability. Specifically, if there are up to $20 \%$ women in the management board a bank's performance improves.

To sum up, the results obtained definitely speak in favour of gender diversity in the management board. First of all, we find that tilted management boards, i. e. management boards having $20-40 \%$ of women, positively influence performance in terms of ROA. As stated by Joecks, Pull and and Vetter (2013) citing Kanter (1997) members of tilted groups influence the culture of the group and are differentiated from each other in their skills and abilities. Furthermore, we find, in terms of NIM, that management boards with up to $20 \%$ of women outperform completely male ones. In skewed group men control the few, i.e. women, controlling also the group and its culture. Although Kanter (1977) cited in Joeck, Pull and Vetter (2013, p. 6) regards skewed groups to be especially problematic since the tokens might be either in the focus or are overlooked, and they may be subject to stereotyping, this finding should be observed in the context of the industry and country in question. Specifically, Croatia as a post-transition country has undergone a long period of transition from self-managing socialism with no preconditions for greater gender diversity development. This particularly refers to the banking industry, where leading positions used to be dominantly held by men, and therefore even slight improvement is welcomed. Finding support for a critical mass of women in the boardroom is particularly important in light of a proposed EU Directive with the aim of attaining a $40 \%$ quota of women in non-executive boardmember positions.

The finding that female chairs of supervisory boards have a positive impact on performance when measured with NIM supports resource based theory. As suggested by Shrader, Blackburn and Illes (1997, p. 359) citing Rosener (1995), women have extraordinary managerial skills in that they are good at seeing big picture issues and can have a strong impact as top managers on productivity, morale and profit. Moreover, the positive influence of women acting as chairperson can be explained by the fact, as stated by Adams and Ferreira (2009, p. 291), that female directors have better attendance records and that gender diverse boards allocate more efforts to monitoring. This is also supported by findings in terms of ROA, where a completely male supervisory boards inhibit performance. However, when adding more women onto a board, performance deteriorates, which is found in models with ROE and NIM as dependent variables.

Although to the authors' knowledge there are no papers exploring the critical mass of women in the boardroom of Croatian companies, there are papers dealing with board characteristics that influence performance. E.g. Pavic Kramaric and Pervan (2016) examined how board structure affects the performance of Croatian banks. Their analysis was also conducted on a sample of Croatian banks in the 2002-2013 period. It differs from our research in that it uses only four measures of board structure and includes neither dummy variables constructed on critical mass theory nor various other controls. Moreover, the aforementioned authors have used only ROA as a dependent variable. Their results, obtained by employing an ArellanoBover/Blundell-Bond estimator, show that the growth of the proportion of women in both management and supervisory boards negatively affects bank performance. Furthermore, Pavic Kramaric, Milun and Pavic (2016) examined how gender diversity in the boardroom of Croatian listed firms influence performance measured by Tobin's q. Their research is conducted on a sample of listed firms in 2014 that belong to different industries and uses linear regression analysis. The results suggest a positive and significant influence from women in management boards on the financial success of the firm. 


\section{CONCLUSION}

The question of how boardroom structure, especially in terms of its gender composition, affects performance has been largely investigated, but there is still no clear consensus on whether such a relationship exists.

This paper brings new evidence on how gender diversity plays an important role in influencing performance, and contributes to the current debate on gender-diversified boardroom by suggesting that banks could benefit from more diverse boards.

Specifically, using an unbalanced static panel analysis on a sample of all commercial banks that operated in the 2002-2014 period, three models were estimated using ROA, ROE and NIM as dependent variables. The board composition variables include the gender of the chairperson, the size of the board, the share of women on the board and four dummy variables constructed on critical mass theory, specifically uniform group, skewed group, tilted group and balanced group. Other controls employed in the model comprise capital adequacy, growth rate of assets on the bank level, ownership, age and a crisis dummy. The empirical results suggest capital adequacy has a positive and significant impact on performance when it is measured with ROA, as is the case with the ownership variable. Older banks have a negative influence on performance in all three models. Moreover, the crisis variable significantly affects performance when performance is measured with ROA and ROE, suggesting the procyclical nature of bank profitability. The size of the supervisory board is significant only in the model with ROA as dependent variable, where it has a positive influence.

In the context of gender diversity, the results obtained suggest a significant and positive influence on performance with respect to ROA and NIM. Our findings are interesting in the context of the primary goal of this research, which was to examine the critical mass of women in the boardroom that influences performance. This is particularly important in light of a proposed EU Directive with the aim of attaining a $40 \%$ quota for women in non-executive board-member positions.

Since we prove the existence of a critical mass of women of $30 \%$ or $40 \%$ in the management board for a significant influence on performance, one cannot claim that there is no scientific ground for imposing a quota of $30 \%$ or $40 \%$ as some EU countries have already done. The results speak in favour of promoting gender balance in the labour market and emphasize the necessity of companies to evolve so as to hire highly skilled women in their decision-making process. As a consequence, this will demonstrate the intention of respecting EU principles and the value of equality.

However, our research has certain limitations, since there might be other factors influencing performance that have not been taken into account. Future research might encompass how a critical mass of $20 \%$ of women translates into an absolute number of women on the board. Additionally, it might be useful to see the influence of gender diversity on performance, not only in leading positions but in the bank as a whole. Furthermore, one of the possible directions for future research might be the inclusion of a stock-performance measure such as Tobin's $Q$.

\section{REFERENCES}

Adams, R. B. and Ferreira, D. 2009. Women in the boardroom and their impact on governance and performance. Journal of Financial Economics 94: 291-309.

Athanasoglou, P. P., Brissimis, S. N. and Delis, M. D. 2005. Bank-Specific, Industry Specific and Macroeconomic Determinants of Bank Profitability. Bank of Greece. Working paper No 25: 4-37.

Barta, T., Kleiner, M., and Neumann, T. 2012. Is there a payoff from top-team diversity?. McKinsey Quarterly. http:// jofisher.com.au/pdf/ McKinsey_Quarterly_April2012.pdf (accessed February 19, 2016).

Baumgärtner, S. 2006. Measuring the diversity of what? And for what purpose? A conceptual comparison of ecological and economic biodiversity indices. Working paper. http://papers.ssrn.com/sol3/papers.cfm?abstract_ id=894782 (accessed February 19, 2016).

Ben Naceur, S. 2003. The determinants of the Tunisian banking industry profitability: panel evidence. Universite Libre de Tunis working papers. http://www.mafhoum. com/press6/174E11.pdf (accessed March 10, 2016).

Bonin, J. P., Hasan, I. and Wachtel, P. 2004. Bank performance, efficiency and ownership in transition countries. Bank of Finland, Institute for Economies in Transition - BOFIT Discussion Papers No. 7: 5-30. https://helda.helsinki.fi/bof/bitstream/handle/123456789/8048/113144. pdf? sequence $=1 \&$ isAllowed $=y$ (accessed June 102, 2016)

Campbell, K. and Minguez-Vera, A. 2007. Gender Diversity in the Boardroom and Firm Financial Performance. Journal of Business Ethics 83: 435-451.

Carter, D. A., Simkins, B. J. and Simpson, W. G. 2003. Corporate Governance, Board Diversity, and Firm Value. The Financial Review 38 (1): 33-53.

Carter, D. A., Souza, F. D., Simkins, B. J. and Simpson, W. G. 2010. The Gender and Ethnic Diversity of US Boards and Board Committees and Firm Financial Performance. 
Corporate Governance: An International Review 18 (5): 396-414.

Chartered Institute of Personnel and Development - CIPD, EU Briefing, Gender diversity on boards: do quota systems work?, https://www.cipd.co.uk/binaries/gender-diversity-on-boards-quota-systems-work_june-2015.pdf (accessed October 1, 2016).

Claessens, S., Demirgüç-Kunt, A. and Huizinga, H. 2001. How does foreign entry affect domestic banking markets?. Journal of Banking \& Finance 25: 891-911.

Credit Institutions Act (Official Gazette No. 59/2013, 19/2015 and 102/2015), http://www.hnb.hr/ documents/20182/506024/e-zakon-o-kreditnim-institucijama-159-2013_19-2015.pdf/fcdde38c-f497-467aad4e-a1a8c554ebc0 (accessed October 1, 2016).

Coad, A., Segarra, A. and Teruel, M. 2013. Like milk or wine: Does firm performance improve with age?. Structural Change and Economic Dynamics, 24: 173-189.

Croatian National Bank, Banks Bulletin No. 29, 2016, http: //www.hnb.hr/documents/20182/950978/ebilteno-bankama-29.pdf/600f3b4b-068d-4f4b-9e571ccaca19aabf (accessed October 5, 2016).

Crutchley Lending, C. and Vähämaa, E. 2016. European board structure and director expertise: The impact of quotas. Research in International Business and Finance 39: 486-501.

Dalton, D. R., daily, C. M., Johnson, J. L. and Ellstrand, A. E. 1999. Number of Directors and Financial Performance: $A$ Meta-Analysis. Academy of Management Journal 42 (6): 674-686.

De Cabo, R. M., Nogués, R. G. and Nieto, M. J. 2012. Gender Diversity on European Banks' Board of Directors: Traces of Discrimination. Journal of Business Ethics 109 (2): 145-162.

Demirgüç-Kunt, A. and Huizinga, H. 2011. Do we need big banks? Evidence on performance, strategy and market discipline. World Bank Policy Research Working Paper No. 5576, http://papers.ssrn.com/sol3/papers.cfm?abstract_ $\mathrm{id}=1774423$ (accessed October 5, 2016).

Demirgüç-Kunt, A. and Huizinga, H. 1999. Determinants of commercial bank interest margins and profitability: some international evidence. World Bank Economic Review 13(2): 379-408.

Dietrich, A. and Wanzenried, G. 2011. Determinants of bank profitability before and during the crisis: Evidence from Switzerland. Journal of International Financial Markets, Institutions and Money 21 (3): 307-327.

Dobbin, F. and Jung, J. 2011. Corporate Board Gender Diversity and Stock Performance: The Competence Gap or Institutional Investor Bias?. North Carolina Law Review 89: 809-838.

Erhardt, N.L., Werbel, J.D., Shrader, C.B. 2003. Board of director diversity and firm financial performance. Corporate Governance: Int. Rev. 11: 102-111.
European Commission, The current situation of gender equality in Spain - Country Profile, 2012, http:// ec.europa.eu/justice/genderequality/files/epo_campaign/130911_country-profile_spain.pdf (accessed October 2, 2016).

European Commission, Gender Equality, Gender balance in decision-making positions, http://ec.europa.eu/justice/ gender-equality/gender-decision-making/database/ business-finance/supervisory-board-board-directors/index_en.htm (accessed October 2, 2016).

European parliament, The Policy on Gender Equality in Germany, 2015, http://www.europarl.europa.eu/ RegData/etudes/IDAN/2015/510025/IPOL_IDA(2015) 510025_EN.pdf (accessed October 2, 2016).

Farrell, K. A. and Hersch, P. L. 2005. Additions to corporate boards: The effect of gender. Journal of Corporate Finance 11 (1\&2): 85-106.

Fields, M. A. and Keys, P.Y. 2003. The Emergence of Corporate Governance from Wall St. to Main St.: Outside Directors, Board Diversity, Earnings Management, and Managerial Incentives to Bear Risk. The Financial Review 38 (1): 1-24.

Fok, R. C. W., Chang, Y. and Lee, W. 2004. Bank Relationships and their Effects on Firm Performance around the Asian Financial Crisis: Evidence from Taiwan. Financial Management 89-112.

Francoeur, C., Labelle, R. and Sinclair-Desgagne, B. 2007. Gender Diversity in Corporate Governance and Top Management. Journal of Business Ethics 81 (1): 83-95.

Hardwick, P., Adams, M. and Zou, H. 2011. Board Characteristics and Profit Efficiency in the United Kingdom Life insurance Industry. Journal of Business Finance \& Accounting 38 (7\&8): 987-1015.

Herring, C. 2009. Does Diversity Pay?: Race, Gender, and the Business Case for Diversity. American Sociological Review 74 (2): 208-224.

Huang, L. Y., Lai G. C., McNamara M. and Wang, J. 2011. Corporate Governance and Efficiency: Evidence from U. S. Property-liability Insurance Industry. The Journal of Risk and Insurance 78 (3): 519-550.

Kanter, R. M. 1977. Men and Women of the Corporation, Basic Books, New York: 206-242.

Konrad, A. M. and Kramer, V. 2006. How many women do boards need?. Harvard business review, 84 (12): 22.

Loderer, C. and Waelchli, U. 2010. Firm Age and Performance, MPRA Paper No 26450.

Jensen, M. C. 1993. The Modern Industrial Revolution, Exit, and the Failure of Internal Control Systems. Journal of Finance 48 (3): 831-880.

Jeon, Y. and Miller, S. M. 2005. Bank Performance: Market Power or Efficient Structure? University of Connecticut. Economic Working Papers, Paper 2005-23.

Joecks, J., Pull, K., and Vetter, K. 2013. Gender Diversity in the Boardroom and Firm Performance: What Exactly 
Constitutes a Critical Mass?. Journal of Business Ethics 118 (1):61-72.

Lee, J. 2009. Does Size Matter in Firm Performance? Evidence from US Public Firms. International Journal of the Economics of Business 16 (2): 189-203.

Lipton, M. and Lorsch, J. 1992. A modest proposal for improved corporate governance. Business Lawyer 48: 59-77.

Lückerath-Rovers, M. 2013. Women on boards and firm performance. Journal of Management \& Governance 17 (2): 491-509.

Ongore, V. O. and Kusa, G. B. 2013. Determinants of Financial Performance of Commercial Banks in Kenya. International Journal of Economics and Financial Issues 3 (1): 237-252.

Pathan, S. and Faff, R. 2013. Does board structure in banks really affect their performance?. Journal of Banking \& Finance 37 (5): 1573-1589.

Pavic Kramaric, T. and Pervan, M. 2016. Does Board Structure Affect the Performance of Croatian Banks?. Journal of Financial Studies and Research. 16:1-10.

Pavic Kramaric, T., Milun, T. and Pavic, I. 2016. Does Gender Diversity in the Boardroom Influence Tobin's $Q$ of Croatian Listed Firms?. International Journal of Economic Sciences, 5 (3).

Pessarossi, P. and Weill, L. 2013. Do capital requirements affect bank efficiency? Evidence from China. BOFIT Discussion Papers 28, https://helda.helsinki.fi/bof/bitstream/handle/123456789/8311/172742.pdf?sequence $=1 \quad$ (accessed November, 8 2016).

Rasmussen, J. L. and Huse, M. 2011. Corporate Governance in Norway: Women Directors and Employee Elected Board Members: 121-146 in Mallin, C. (ed.), Handbook on International Corporate Governance - Country Analysis, Elgar, Cheltenham

Sameh, J., Bouzgarrou, H. and Louhichi, W. 2016. Bank Profitability during and before Financial Crisis: Domestic vs. foreign banks, International Symposium in Computational Economics and Finance, Paris - France, Vol. 4th
Shrader, C. B., Blackburn, V. and Illes, P. 1997. Women in Management and Firm Financial Performance: An Exploratory Study. Journal of Managerial Issues 9 (3): 355-372.

Schuknecht, L., von Hagen, J. and Wolswijk, G. 2010. Government bond risk premiums in the EU revisited the impact of the financial crisis. European Central Bank, Working Paper Series, No 1152

Solanas, A., Selvan, R. M., Navarro, J. and Leiva, D. 2012. Some Common Indexes of Group Diversity: Upper Boundaries. Working paper. http://diposit.ub.edu/ dspace/bitstream/2445/45784/1/623311.pdf also available at Proceedings of Measuring Behavior. 2012, Utrecht, The Netherlands, http://www.measuringbehavior.org/ files/2012/ProceedingsPDF\%28website\%29/Posters/ Solanas_et_al_MB2012.pdf (accessed December, 8 2015).

Staikouras, C. K. and Wood, G. E. 2004. The Determinants of European Bank Profitability. International Business\&Economic Research Journal 3 (6): 57-68.

Tipuric, D. et al. (2015) Korporativno upravljanje u Hrvatskoj: ocjena kvalitete korporativnog upravljanja hrvatskih dioničkih društava SEECGAN metodologijom (Corporate governance in Croatia: assessment of quality of corporate governance in Croatian joint stock companies using SEECGAN methodology), CIRU - Centar za istraživanje i razvoj upravljanja

Torchia, M., Calabrò, A. and Huse, M. 2011. Women Directors on Corporate Boards: From Tokenism to Critical Mass. Journal of Business Ethics 102 (2): 299-317.

Villanueva-Villar, M., Rivo-López, E. and Lago-Peñas, S. 2016. On the relationship between corporate governance and value creation in an economic crisis: Empirical evidence for the Spanish case. BRQ Business Research Quarterly 19 (4): 233-245.

Yermack, D. 1996. Higher market valuation of companies with a small board of directors. Journal of Financial Economics 40 (2): 185-211. 


\section{APPENDIX 1: Description of variables used in the model}

\begin{tabular}{|c|c|}
\hline Variable & Calculation \\
\hline ROA & It is calculated by dividing a company's after tax annual profits by its total assets \\
\hline ROE & It is calculated by dividing a company's after tax annual profits by its total equity \\
\hline NIM & It is calculated as net interest income divided by total assets \\
\hline CAP & $\begin{array}{l}\text { Capital adequacy ratio variables were obtained directly from various issues of } \\
\text { Banks Bulletin of Croatian National Bank }\end{array}$ \\
\hline GROWTH_ASSETS & Growth rate of assets is calculated using the following formula: \\
\hline LN_ASSETS & Size variable is calculated as the natural logarithm of total assets \\
\hline MS & $\begin{array}{l}\text { It is calculated as assets of an individual bank divided by the total assets of the } \\
\text { banking industry in a particular year }\end{array}$ \\
\hline OWN & $\begin{array}{l}\text { Dummy variable that takes value } 1 \text { for domestic banks while } 0 \text { refers to foreign } \\
\text { owned banks }\end{array}$ \\
\hline AGE & $\begin{array}{l}\text { The natural logarithm of the number of years the bank operated in the market, } \\
\text { i.e. as the current year of the analysis reduced by the foundation year of the bank }\end{array}$ \\
\hline CRISIS_dummy & $\begin{array}{l}\text { Dummy variable that takes value } 1 \text { if the country is going through crisis (in the } \\
2009-2014 \text { period when negative GDP growth rates were registered) and } 0 \text { oth- } \\
\text { erwise, i. e. in the } 2002-2008 \text { period }\end{array}$ \\
\hline $\begin{array}{l}\text { CHAIR_MB_dummy/CHAIR_SB } \\
\text { _dummy }\end{array}$ & $\begin{array}{l}\text { Dummy variable referring to the gender of the chairperson of the management/ } \\
\text { supervisory board that takes value } 1 \text { in the board with female president and } 0 \\
\text { otherwise }\end{array}$ \\
\hline LN_SIZE_MB/LN_SIZE_SB & $\begin{array}{l}\text { It is calculated as natural logarithm of the total number of management/supervi- } \\
\text { sory board members }\end{array}$ \\
\hline SHARE_W_MB/SHARE_W_SB & $\begin{array}{l}\text { The share of women in the management/supervisory board is calculated as the } \\
\text { number of board female members divided by the total number of management/ } \\
\text { supervisory board members }\end{array}$ \\
\hline BLAU_MB/BLAU_SB & $\begin{array}{l}\text { It is calculated as where pi is the percentage of management/supervisory board } \\
\text { members in each category (men and women) and } \mathrm{n} \text { is the total number of man- } \\
\text { agement/supervisory board members }\end{array}$ \\
\hline SHANNON_MB/SHANNON_SB & $\begin{array}{l}\text { It is calculated as where pi is the percentage of management board members } \\
\text { in each category (men and women) and } n \text { is the total number of management } \\
\text { board members }\end{array}$ \\
\hline $\begin{array}{l}\text { UNIFORM_MB_dummy/UNIFORM_ } \\
\text { SB_dummy }\end{array}$ & $\begin{array}{l}\text { Dummy variable that takes value } 1 \text { if there are no women on the management/ } \\
\text { supervisory board and } 0 \text { otherwise }\end{array}$ \\
\hline $\begin{array}{l}\text { SKEWWED_MB_dummy/SKEWWED_ } \\
\text { SB_dummy }\end{array}$ & $\begin{array}{l}\text { Dummy variable that takes value } 1 \text { if there are up to } 20 \% \text { women on the manage- } \\
\text { ment/supervisory board and } 0 \text { otherwise }\end{array}$ \\
\hline $\begin{array}{l}\text { TILTED_MB_dummy/TILTED_SB } \\
\text { _dummy }\end{array}$ & $\begin{array}{l}\text { Dummy variable that takes value } 1 \text { if there are between } 20-40 \% \text { women on the } \\
\text { management/supervisory board and } 0 \text { otherwise }\end{array}$ \\
\hline $\begin{array}{l}\text { BALANCED_MB_dummy/ } \\
\text { BALANCED_SB_dummy }\end{array}$ & $\begin{array}{l}\text { Dummy variable that takes value } 1 \text { if there is at least } 40 \% \text { on the management/ } \\
\text { supervisory board and } 0 \text { otherwise }\end{array}$ \\
\hline
\end{tabular}

